The University of Southern Mississippi

The Aquila Digital Community

Faculty Publications

$4-1-2013$

\title{
Diel Vertical Movements of a Scalloped Hammerhead, Sphyrna lewini, in the Northern Gulf of Mexico
}

Eric R. Hoffmayer

National Marine Fisheries Service

James S. Franks

University of Southern Mississippi, jim.franks@usm.edu

William B. Driggers

National Marine Fisheries Service

Paul W. Howey

Microwave Telemetry, Inc.

Follow this and additional works at: https://aquila.usm.edu/fac_pubs

Part of the Marine Biology Commons

\section{Recommended Citation}

Hoffmayer, E. R., Franks, J. S., Driggers, W. B., Howey, P. W. (2013). Diel Vertical Movements of a Scalloped Hammerhead, Sphyrna lewini, in the Northern Gulf of Mexico. Bulletin of Marine Science, 89(2), 551-557. Available at: https://aquila.usm.edu/fac_pubs/7752

This Article is brought to you for free and open access by The Aquila Digital Community. It has been accepted for inclusion in Faculty Publications by an authorized administrator of The Aquila Digital Community. For more information, please contact Joshua.Cromwell@usm.edu. 


\title{
DIEL VERTICAL MOVEMENTS OF A SCALLOPED HAMMERHEAD, SPHYRNA LEWINI, IN THE NORTHERN GULF OF MEXICO
}

\author{
Eric $R$ Hoffmayer, James S Franks, \\ William B Driggers III, and Paul W Howey
}

\begin{abstract}
Despite the circumglobal distribution of scalloped hammerheads, Sphyrna lewini (Griffith and Smith, 1834), little information is available regarding finescale movement and habitat use patterns for this species. Over a $27-\mathrm{d}$ period, data were collected on diel habitat use and environmental preferences of a $240 \mathrm{~cm}$ (total length) female $S$. lewini. The shark exhibited a consistent and repeated diel vertical movement pattern, making more than 76 deep nighttime dives; the maximum depth reached was $964 \mathrm{~m}$, where the temperature was $5.8^{\circ} \mathrm{C}$. The purpose of the nightly oscillatory deep diving pattern is unknown but could possibly represent feeding behavior. These findings represent the first detailed account of $S$. lewini diel vertical behavior and habitat utilization in the western North Atlantic Ocean.
\end{abstract}

The scalloped hammerhead, Sphyrna lewini (Griffith and Smith, 1834), is a large shark species that occurs worldwide in tropical, subtropical, and temperate marine waters (Compagno 1984). In the western North Atlantic Ocean, S. lewini occurs from New Jersey to Brazil, including the Caribbean Sea and Gulf of Mexico (GOM; Compagno 1984). In the northern GOM, S. lewini is distributed throughout the region in coastal and offshore waters (NMFS unpubl data); however, detailed knowledge of their ecology, behavior, and habitat requirements is limited. In June 2008, we opportunistically encountered a large school of S. lewini in offshore waters off the coast of Louisiana and were able to deploy a high-rate pop-up archival satellite tag (PSAT) on an adult female shark to describe its short term water depth and temperature preferences. We report the first account of diel vertical movements of S. lewini in the GOM.

\section{Materials ANd Methods}

On 19 June, 2008, a female S. lewini was caught using hook-and-line gear in surface waters adjacent to a petroleum platform (MC582) located in the Mississippi Canyon $60 \mathrm{~km}$ south of the Mississippi River Delta's Southwest Pass (Fig. 1). The platform is positioned in $678 \mathrm{~m}$ of water at $28.392^{\circ} \mathrm{N}$ and $89.454^{\circ} \mathrm{W}$.

The shark was hooked and brought alongside the boat where it was sexed (female), measured (240 cm total length), and tagged with a high-rate PSAT (PTT-100HR, Microwave Telemetry, Inc.). The tag anchor was inserted into the shark's dorsal musculature at the base of the first dorsal fin. The tag was attached to an umbrella nylon dart anchor $(1 \times 3 \mathrm{~mm}$; Domeier et al. 2005 ) with a 15.0 -cm segment of $1.8-\mathrm{mm}$ monofilament line that was wrapped with $3.2-\mathrm{mm}$ marine grade heat shrink tubing. Following tag attachment, the hook was removed and the shark was released.

The PSAT measured $34.0 \mathrm{~cm}$ in length (including the $17.0 \mathrm{~cm}$ antenna), $1.6 \mathrm{~cm}$ in diameter at its widest point, and weighed $68 \mathrm{~g}$ in air. The PTT-100HR recorded and archived water 


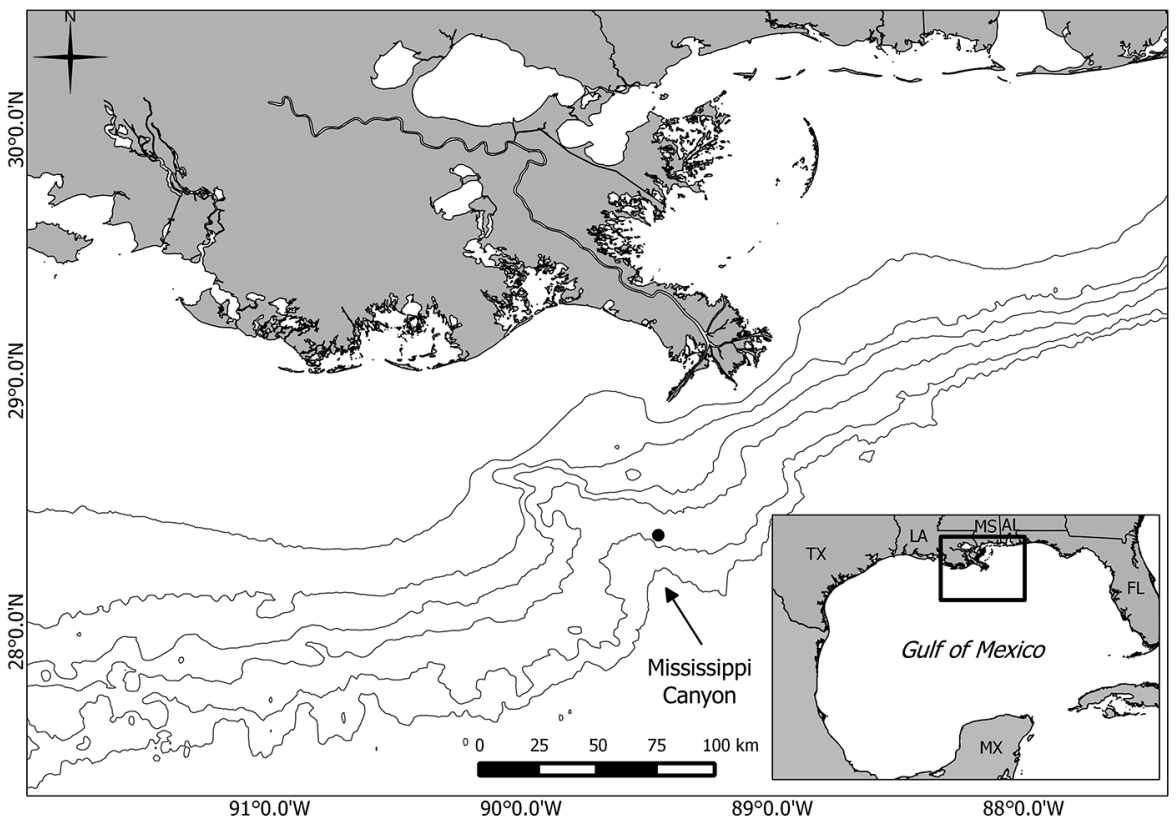

Figure 1. Map of the northern Gulf of Mexico showing the pop-up archival satellite tagging location (black circle) for the scalloped hammerhead, Sphyrna lewini. The 50, 100, 200, 400, 800, and $1000 \mathrm{~m}$ isobaths are indicated by black lines. The black circle represents the location of the petroleum platform, the tagging, and initial pop-up location, since all three occurred within 1.3 $\mathrm{km}$ of each other.

temperature $\left( \pm 0.2^{\circ} \mathrm{C}\right)$ and pressure (depth; $\left.\pm 2.7 \mathrm{~m}\right)$ every $4 \mathrm{~min}$. Due to battery limitations associated with increased resolution of temperature and depth data, the high-rate PSAT did not collect light-based geolocation data, so horizontal movements were not assessed. The tag was programmed to detach from the tether after $30 \mathrm{~d}$, float to the surface, and upload archived data to the Argos satellite system.

For analytical purposes, depth and temperature measurements were stratified by daytime and nighttime using estimates of sunrise (06:05) and sunset (20:03) times at the tagging location calculated by the US Naval Observatory (http://aa.usno.navy.mil). Time-at-depth and time-at-temperature histograms were generated at $20-\mathrm{m}$ (depth) and ${ }^{\circ} \mathrm{C}$ (temperature) intervals and were separated by daytime and nighttime. The local mixed layer depth (MLD) was estimated using three CTD casts (Seabird SBE 911) conducted $<50 \mathrm{~km}$ from the study site from July 13-16, 2008.

To examine diving behavior, individual dives were defined as vertical excursions that began in the mixed layer $(<35 \mathrm{~m})$, exceeded $300 \mathrm{~m}$ in depth, and were followed by a return to the mixed layer. Descent and ascent rates were also calculated. The descent phase of the dive began in surface waters $(<35 \mathrm{~m})$ and ended when the shark reached the maximum depth of the dive. The ascent phase began at the maximum depth of the dive and ended as the shark re-entered surface waters. If the dive was interrupted by multiple missing data points, then ascent and descent rates were not calculated. Mean rate of change $\left(\mathrm{m} \mathrm{s}^{-1}\right)$ was calculated by dividing the depth difference by the time interval. Since the entire data set was not uploaded to the satellite, data points were grouped by hour and day and Pearson's chi-squared tests were used to determine if the missing values were evenly distributed throughout the data set. For statistical tests, results were considered significant at $P<0.05$. Mean values are presented with standard error. 


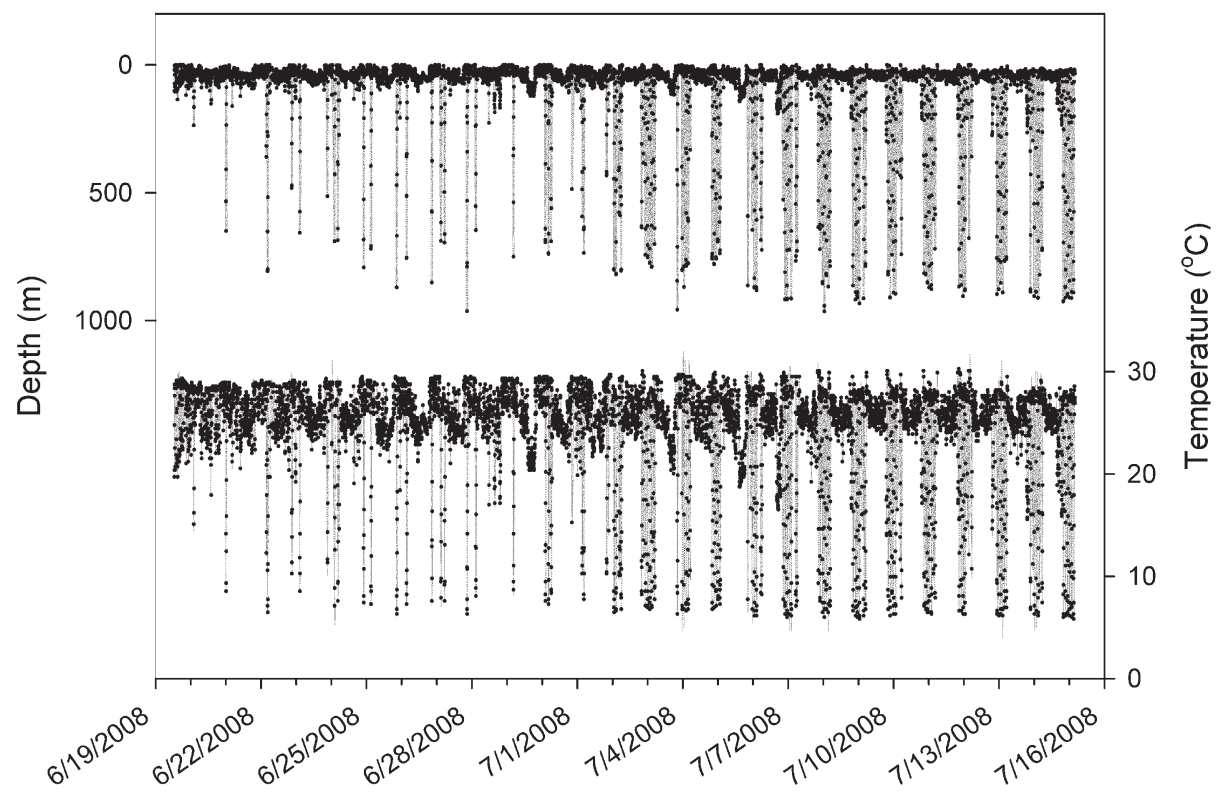

Figure 2. Measurements of depth and temperature recorded every 4 min during the 27-d pop-up archival satellite tag track of the scalloped hammerhead, Sphryna lewini.

\section{RESUlts}

The PSAT detached from the shark on 15 July, 2008, "uplinked" to the Argos system, and transmitted archived data over a $21-\mathrm{d}$ period. The tag was first detected by the Argos satellite system $1.3 \mathrm{~km}(0.83 \mathrm{~nm})$ northeast of the deployment location at $09: 38,5.8$ hrs after detachment. Only $20 \%$ of the data recorded by the tag was not recovered through the satellite and the missing data were evenly distributed among hours (chi-squared: $\mathrm{X}_{23}^{2}=26.7, P=0.27$ ) and days (chi-squared: $\mathrm{X}_{23}^{2}=25.4, P=0.38$ ).

Immediately following tagging on 19 June, 2008, the shark dove to $102 \mathrm{~m}$ and spent the remaining daylight hours between 20 and $60 \mathrm{~m}$. During the duration of the tag deployment, the shark remained in relatively shallow waters $(<60 \mathrm{~m})$ during daytime and made multiple nightly dives to depths to $964 \mathrm{~m}$ (Figs. 2-3), which is well within the tag's maximum depth range of $1296 \mathrm{~m}$.

Daytime depths ranged from 0 to $228 \mathrm{~m}$, with the shark spending $83.4 \%$ of its time between 20 and $80 \mathrm{~m}$. Nighttime depths ranged from 0 to $964 \mathrm{~m}$, with the shark spending $71.7 \%$ of its time in surface/near-surface waters between 0 and $60 \mathrm{~m}$, and $16.4 \%>241 \mathrm{~m}$. The shark made more than 76 nighttime deep dives $(>700 \mathrm{~m})$, with 16 dives exceeding $900 \mathrm{~m}$ (Fig. 2-3) throughout the tag deployment. The MLD was estimated to be between 33 and $35 \mathrm{~m}$. The shark spent its time as: $32.7 \%$ within and $67.3 \%$ below the MLD during daytime, and $60.3 \%$ within and 39.7\% below the MLD during nighttime. 


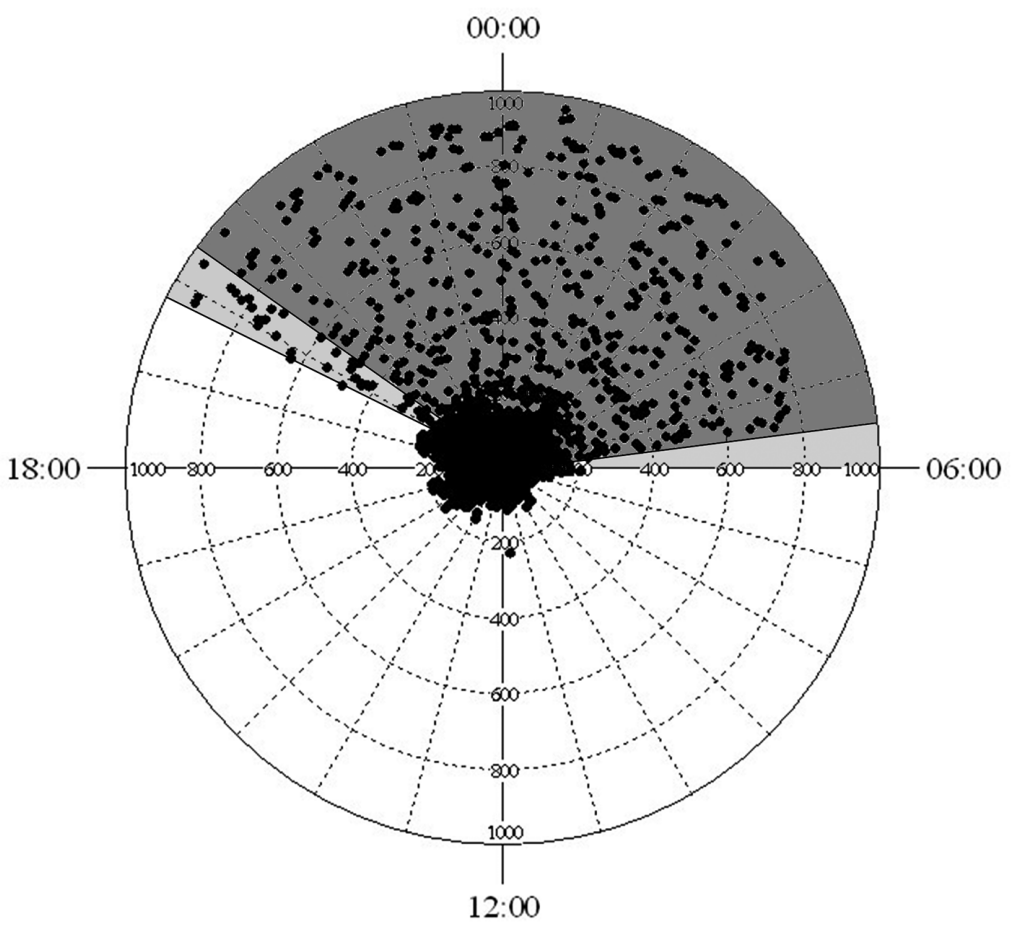

Figure 3. Circular-linear plot depicting depth distribution data recorded for the pop-up archival satellite tagged scalloped hammerhead, Sphryna lewini, over the 27-d of the study. Inner axes represent instantaneous depth (m) and the outer axis represents time of day (24 hrs). The light gray shaded area represents morning and evening civil twilight, whereas the dark gray shaded area represents nighttime.

Over the 27-d study period, the shark experienced water temperatures ranging from 5.8 to $30.3^{\circ} \mathrm{C}$ (Fig. 2). Daytime temperatures ranged from 13.1 to $30.1{ }^{\circ} \mathrm{C}$, with the shark spending $87.3 \%$ of the daytime at 23 to $28{ }^{\circ} \mathrm{C}$. Nighttime temperatures ranged from 5.8 to $30.3{ }^{\circ} \mathrm{C}$, with the shark spending $59.9 \%$ of the nighttime at 26 to $28^{\circ} \mathrm{C}$ and $19.4 \%$ of the nighttime at $<16^{\circ} \mathrm{C}$.

The mean number of deep dives per night was 4.2 (SE 0.49) with a mean duration of 41.6 (SE 1.4) $\mathrm{min}$ and a mean dive depth of 795.9 (SE 12.3) $\mathrm{m}$. The mean estimated descent time and rate were 10.8 (SE 0.3) min and 1.31 (SE 0.03) $\mathrm{m} \mathrm{s}^{-1}$, and the mean estimated ascent time and rate was 26.9 (SE 0.6) $\mathrm{min}$ and 0.51 (SE 0.01) $\mathrm{m} \mathrm{s}^{-1}$. The approximate time at maximum depth for dives $>700 \mathrm{~m}$ was $4 \mathrm{~min}$. The surface/nearsurface time interval spent between deep diving events ranged from 35 to $45 \mathrm{~min}$ [mean: 40.2 (SE 1.2) min]. Typically, the first descent each night began at dusk and the last ascent occurred just before sunrise [mean first descent time: 20:29 (SE 0:06), last ascent time: 04:53 (SE 0:15)].

\section{Discussion}

This study represents the first record of PSAT technology used to collect environmental preference and movement data for a S. lewini in the western North Atlantic. 
Tag data revealed fine-scale vertical movements, including a pronounced diel vertical migration pattern within a larger vertical niche than was previously known for this species. Jorgensen et al. (2009) reported vertical movements of a PSAT-tagged $S$. lewini over a 74-d period in the Gulf of California that included four dives $>900 \mathrm{~m}$, which exceeded the previously known greatest depth $(475 \mathrm{~m})$ attained by this species (Klimley 1993). In our 27-d study, the PSAT-tagged shark made 76 nighttime dives $>700 \mathrm{~m}$ in depth, 16 of which were $>900 \mathrm{~m}$, suggesting this is a common behavior for this species. However, tagging of additional individuals is required to verify the degree to which the observed behavior is common. Further, it should be noted that during the first $2 \mathrm{~d}$ after tagging, the shark showed limited vertical movements in the water column, which possibly represented a post-release behavior modification similar to what has been identified in other large pelagic fishes (Hoolihan et al. 2011).

The proximity of the PSAT's location to the MC582 platform shortly after its release from the shark suggests a possible affinity by the shark for the platform throughout tag deployment. Based on the depths of the dives, the shark most likely moved into adjacent, deeper waters of the Mississippi Canyon during nighttime and returned to the petroleum platform at dawn where it remained during daytime. Klimley et al. (1988) found that S. lewini aggregate at seamounts in the Gulf of California during daytime when no feeding was observed. Sharks then departed the seamount at dusk to forage in the surrounding pelagic environment and returned to the seamount by dawn on the following morning (Klimley and Nelson 1984, Klimley 1985, Klimley et al. 1988). If the shark tagged in the present study was using MC582 in a manner similar to conspecifics using seamounts in the Gulf of California, then petroleum platforms and salt domes in the GOM could provide similar function for S. lewini.

One of the most common behaviors of large pelagic fishes in the open ocean environment is oscillatory swimming, which could be related to energy conservation, behavioral thermoregulation, navigation, or feeding (West and Stevens 2001, Klimley et al. 2002). Weihs (1973) suggested that oscillatory swimming with a swim-glide mode of progression is a more efficient form of locomotion than straight line swimming and can serve as a means of "resting" or energy conservation. However, the dive profile of the tagged S. lewini revealed a "fast descent" and "slow ascent" profile, which has been reported for other shark species (Carey and Scharold 1990, Nakano et al. 2003, Cartamil et al. 2011) and is not consistent with the energy conservation hypothesis. Another proposed function of oscillatory swimming pattern observed in pelagic fishes is behavioral thermoregulation. The $40 \mathrm{~min}$ surface interval within the MLD consistently observed between deep diving events could have served as a "warming" period to recover from heat loss prior to the next dive into cold depths, and allowed the shark to maximize its time at depth, as suggested by Carey and Scharold (1990) for blue sharks.

The shark's nightly deep dives most likely represented feeding excursions targeting deep water prey, as suggested for other pelagic fishes exhibiting similar diving patterns (Holland et al. 1992, Schaefer and Fuller 2002, Wilson et al. 2005, Musyl et al. 2011). Although a deep oscillatory diving pattern was reported in S. lewini in other oceans (Klimley 1987, Klimley 1993, Jorgensen et al. 2009), none of these studies acquired high resolution data similar to what is presented here. The S. lewini in our study descended at a relatively high speed (up to $2.1 \mathrm{~m} \mathrm{~s}^{-1}$ ) to a similar depth on each consecutive dive, suggesting that the shark was not feeding on its descent, but most likely while on the bottom or during ascent. The shark could have been feeding on 
benthic prey items such as deep water batoids, which are known to occur in the diet of S. lewini in the northern GOM (E Hoffmayer, unpubl data). Further evidence for deep diving feeding behavior is found in dietary studies of $S$. lewini that report a high incidence of mesopelagic teleosts, mesopelagic cephalopods, and deep water crustaceans (Klimley 1987, Stevens and Lyle 1989, Smale and Cliff 1998, Júnior et al. 2009).

\section{ACKNOWLEDGMENTS}

We extend our appreciation to B Delabar and BC Bobby of the sport fishing vessel FrENZY (Venice, Louisiana). We also thank R Berg (BEI, Inc.) for providing video of the scalloped hammerhead aggregation at MC582 the day prior to our tagging event. G Parsons provided valuable comments on an earlier version of the manuscript. This research was partially supported by US National Marine Fisheries Service, Cooperative Research Program, Grant \#NA08NMF4540389 to E Hoffmayer and J Franks. This research was conducted in compliance with US law under Scientific Research Permit HMS-EFP-08-07, issued by the Highly Migratory Species Division of the Office of Sustainable Fisheries, National Marine Fisheries Service, Silver Spring, MD 20910, USA, and the Institutional Animal Care and Use Committee of the University of Southern Mississippi (protocol 09031204). Mention of commercial products does not imply endorsement by the University of Southern Mississippi or the National Marine Fisheries Service.

\section{Literature Cited}

Carey FG, Scharold JV. 1990. Movements of blue sharks (Prionace glauca) in depth and course. Mar Biol. 106:329-342. http://dx.doi.org/10.1007/BF01344309

Cartamil DP, Sepulveda CA, Wegner NC, Aalber SA, Baquero A, Graham JB. 2011. Archival tagging of subadult and adult common thresher sharks (Alopias vulpinis) off the coast of southern California. Mar Biol. 158:935-944. http://dx.doi.org/10.1007/s00227-010-1620-4

Compagno LJV. 1984. Sharks of the world. An annotated and illustrated catalogue of shark species known to date. Part 2: Carcharhiniformes. FAO Fish Synop. (125) 4:251-655.

Domeier ML, Kiefer D, Nasby-Lucas N, Wagscal A. 2005. Tracking Pacific bluefin tuna (Thunnus thynnus orientalis) in the northeastern Pacific with an automated algorithm that estimates latitude by matching sea-surface-temperature data from satellite with temperature data from tags on fish. Fish Bull. 103:292-306.

Holland KN, Brill RW, Chang RKC, Sibert JR, Fournier DA. 1992. Physiological and behavioral thermoregulation in bigeye tuna (Thunnus obesus). Nature. 358:410-412. PMid:1641023. http://dx.doi.org/10.1038/358410a0

Hoolihan JP, Luo J, Abascal FJ, Campana SE, De Metrio G, Dewar H, Domeier ML, Howey LA, Lutcavage ME, Musyl MK, et al. 2011. Evaluating irregular post-release behaviour of large pelagic fishes deployed with pop-up satellite archival tags. ICES J Mar Sci. 68:880-889. http://dx.doi.org/10.1093/icesjms/fsr024

Jorgensen ST, Klimiey AP, Muhila-Meio AF. 2009. Scalloped hammerhead shark Sphyrna lewini, utilizes deep-water, hypoxic zone in Gulf of California. J Fish Biol. 74:1682-1687. http:// dx.doi.org/10.1111/j.1095-8649.2009.02230.x

Júnior TV, Vooren CM, Lessa RP. 2009. Feeding strategy of the night shark (Carcharhinus signatus) and scalloped hammerhead sharks (Sphyrna lewini) near seamounts off Northeastern Brazil. Braz J Oceanogr. 57:97-104.

Klimley AP. 1985. Schooling in Sphyrna lewini, a species with low risk of predation: a nonegalitarian state. Z Tierpsychol. 70:297-319.

Klimley AP. 1987. The determinants of sexual segregation in the scalloped hammerhead shark (Sphyrna lewini). Environ Biol Fish. 18:27-40. http://dx.doi.org/10.1007/BF00002325 
Klimley AP. 1993. Highly directional swimming by scalloped hammerhead sharks (Sphyrna lewini) and subsurface irradiance, temperature, bathymetry, and geomagnetic field. Mar Biol. 117:1-22. http://dx.doi.org/10.1007/BF00346421

Klimley AP, Beavers SC, Curtis TH, Jorgensen ST. 2002. Movements and swimming behavior of three species of sharks in La Jolla Canyon, California. Environ Biol Fish. 63:117-135. http:// dx.doi.org/10.1023/A:1014200301213

Klimley AP, Butler SB, Nelson DR, Stull AT. 1988. Diel movements of scalloped hammerhead sharks (Sphyrna lewini Griffith and Smith) to and from a seamount in the Gulf of California. J Fish Biol. 33:751-761. http://dx.doi.org/10.1111/j.1095-8649.1988.tb05520.x

Klimley AP, Nelson DR. 1984. Diel movement patterns of the scalloped hammerhead shark (Sphyrna lewini) in relation to El Bajo Espiritu Santo: a refuging central-position social system. Behav Ecol Sociobiol. 15:45-54. http://dx.doi.org/10.1007/BF00310214

Musyl MK, Brill RW, Curran DS, Fragoso NM, McNaughton LM, Nielsen A, Kikikawa BS, Moyes CD. 2011. Postrelease survival, vertical and horizontal movements, and thermal habitats of five species of pelagic sharks in the central Pacific Ocean. Fish Bull. 109(4):341-368.

Nakano H, Matsunaga H, Okamoto H, Okazaki M. 2003. Acoustic tracking of bigeye thresher shark Alopias superciliosus in the eastern Pacific Ocean. Mar Ecol Prog Ser. 265:255-261. http://dx.doi.org/10.3354/meps265255

Schaefer KM, Fuller DW. 2002. Movements, behavior, and habitat selection of bigeye tuna (Thunnus obesus) in the eastern equatorial Pacific, ascertained through archival tags. Fish Bull. 100:15-28.

Smale MJ, Cliff G. 1998. Cephalopods in the diets of four shark species (Galeocerdo cuvier, Sphyrna lewini, S. zygaena, and S. mokarran) from KwaZulu-Natal, South Africa. In: Payne AIL, Lipinski MR, Clarke MR, Roeleveld MAC, editors. Cephalopod Biodiversity, Ecology, and Evolution. S Afr J Mar Sci. 20:241-253.

Stevens JD, Lyle JM. 1989. Biology of three hammerhead sharks (Eusphyrna blochii, Sphyrna mokarran, and S. lewini) from northern Australia. Aust J Mar Freshw Res. 40(2):129-146. http://dx.doi.org/10.1071/MF9890129

Weihs D. 1973. Mechanically efficient swimming techniques for fish with negative buoyancy. J Mar Res. 31:194-209.

West GJ, Stevens JD. 2001. Archival tagging of school sharks, Galeorhinus galeus, in Australia: Initial results. Environ Biol Fish. 60:283-298. http://dx.doi.org/10.1023/A:1007697816642

Wilson SG, Lutcavage ME, Brill RW, Genovese MP, Cooper AB, Everly AW. 2005. Movements of bluefin tuna (Thunnus thynnus) in the northwestern Atlantic Ocean recorded by pop-up satellite archival tags. Mar Biol. 146:409-423. http://dx.doi.org/10.1007/s00227-004-1445-0

Date Submitted: 22 June, 2012.

DATE ACCEPTED: 17 December, 2012.

Available Online: 8 February, 2013.

AdDresses: (ERH, WBD) National Marine Fisheries Service, Southeast Fisheries Science Center, Mississippi Laboratories, PO Drawer 1207, Pascagoula, Mississippi 39567. (JSF) University of Southern Mississippi, Center for Fisheries Research and Development, Gulf Coast Research Laboratory, 703 East Beach Drive, Ocean Springs, Mississippi 39564. (PWH) Microwave Telemetry, Inc., 8835 Columbia 100 Parkway, Suites KEL, Columbia, Maryland 21045. Corresponding Author: (ERH) Email: <eric.hoffmayer@noaa.gov>.

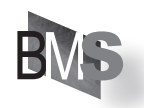

